\title{
HOMENS QUE TRANSFORMAM A CIDADE QUE TRANSFORMA OS HOMENS: O CASO DE CURITIBA
}

Marina Marini Mariotto Belotto Pura Lucia Oliver Martins

"Ao invés de entendermos a cidade como um mero locus geográfico para os fenômenos sociais e técnicos, consideramos essa como uma poderosa ferramenta na construção de novas barreiras entre o próprio social e técnico e, além disso, uma ferramenta para a construção de novos estilos de vida”. (AIBAR, BIJKER, 23, 1997).

Entender a cidade como espaço-tempo educativo, como palco para as diferentes interações sociais é compreendê-la além do seu aspecto físico-geográfico, ultrapassando as barreiras de territorialidade, alcançando seu caráter icônico e memorável (LYNCH, 1997), e alcançando ainda o seu potencial educador para com o cidadão que ali educa, se educa e é educado, contando diferentes histórias. No caso da Cidade de Curitiba, a característica de ícone pela qual essa é conhecida atualmente é resultado de diversos aspectos históricos, culturais, políticos e sociais, que compuseram o seu caráter de Cidade Modelo e que vem educando uma população já por múltiplas gerações, antes mesmo da aplicação do Novo Plano Diretor de 1970 (Casa da Memória de Curitiba). Os desdobramentos políticos nacionais e locais - nem sempre passiveis de diagnóstico positivo ou negativo - serviram de base para toda a retórica da cidade que conhecemos hoje.

Como marco dessa fase “revolucionária”, mais conhecida como "Era Lerner” - sobrenome do prefeito em exercício no período - tem se a pedestrização de uma das vias mais importantes e mais catalizadoras de tráfego de Curitiba: a Rua XV de Novembro. Este fato é considerado por muitos como divisor de águas no planejamento da cidade, bem como um movimento político fundamental para a mudança de paradigmas que se tinha em relação aos habitantes locais. (Entrevista Instituto Jaime Lerner, 2009).

Para compreender de forma global esse fenômeno que aplicou tal nova tecnologia e que foi capaz de incorporar socialmente novos conceitos numa população, buscou-se a teoria SCOT, já que trabalha com a construção social da tecnologia num âmbito no qual existam diferentes grupos sociais relevantes em determinada área com diferentes interesses no artefato e na própria tecnologia aplicada (BIJKER, 2001).

O presente artigo analisa o contexto e o processo nos quais a pedestrização da Rua VX de Novembro da Cidade de Curitiba aconteceu, levando em consideração o foco metodológico da Teoria SCOT, a fim de compreender os diferentes atores envolvidos direta e indiretamente no 
processo, as diversas interpretações existentes para o fenômeno, as formas com as quais as discussões se transformaram em ações bem como o contexto no qual tudo isso aconteceu (BIJKER, 1997). E, para mais além, provocar o pensamento do leitor acerca da construção histórico-social que vem contribuindo para o entendimento de cidade que temos hoje - Curitiba ou qualquer outra-, e como a urbe pode também servir de meio para a educação para além dos muros da escola.

Para atingir os objetivos traçados, é importante ressaltar que a base de referência da época do processo de pedestrização utilizada foi o acervo de microfilmes ${ }^{1}$ da Biblioteca Pública do Paraná das reportagens veiculadas pelo jornal impresso local de maior renome na época, a Gazeta do Povo $^{2}$, especificamente no mês no qual o calçamento aconteceu, já que a intenção é analisar o fato, e não aprofundar sua concepção ou posteriores desdobramentos, ficando aqui demarcado o papel provocador do artigo, e não definidor de posicionamentos ou partidos.

\section{ENTENDENDO A TEORIA SCOT}

Para delinear o formato do trabalho, se faz necessária uma compreensão ampla ao que se refere à Teoria SCOT. Seus autores, Wiebe E. Bijker, Thomas P. Hughes e Trevor Pinch, nos anos 80, formatam o conceito baseado em quatro diferentes diretrizes, porém, complementares. Essa mesma teoria é utilizada por Bijker e Eduardo Aibar em Constructing a City: The Cerdà Plan for the Extension of Barcelona, em 1997 e que, posteriormente, é também utilizada por Bruno Latour, quem em 2007, publica seu livro Reassembling the Social: An Introduction to Actor-NetworkTheory.

A teoria se baseia em quatro componentes que, em conjunto, formam uma rede analítica de aplicação de tecnologia para a construção de um artefato por meio de circunstâncias sociais préexistentes. Esses componentes são: o amplo contexto no qual aquele processo ocorre, ou seja, suas nuances históricas, por exemplo; os diferentes e relevantes grupos sociais envolvidos no mesmo, cujas vivências e interesses culminam em diferentes interpretações desse mesmo fenômeno, provocando assim uma interpretação flexível do fato. Existindo então, para isso, dois possíveis fechamentos - a estabilização de um artefato produzido cuja interpretação provém de um único

\footnotetext{
${ }^{1}$ Devido à baixa qualidade das imagens, optou-se por anexá-las ao final do texto e não no corpo do mesmo, de modo a suprir a curiosidade do leitor quanto ao formato das reportagens.

2 É importante ressaltar que no período analisado, a imprensa passava por mudanças intensas que não serão aprofundadas aqui. Porém, essa condicionante de censura ocorrida no período de ditadura militar no Brasil (1969 1973) fez com que as reportagens encontradas e trabalhadas aqui, como no caso de vários outros jornais do país, não apresentassem autoria direta (GENTILLI, 2004), sendo condicionadas apenas ao jornal Gazeta do Povo como unidade, sem definição especifica de quem escrevia as reportagens.
} 
grupo social relevante ou o possível encerramento no embate de interpretações entre diversos grupos sociais relevantes (KASANG, 2012).

\section{BREVE HISTÓRICO PRELIMINAR}

Desde o início de sua história, a rua que atualmente é conhecida como Rua XV de Novembro, em Curitiba, carrega muito das características de formação urbana, social e cultural da cidade. Por ser uma das primeiras vias idealizadas e instaladas, vem carregando o poder catalizador de eventos culturais desde 1820 - ano no qual já existiam relatos de sua existência (Casa da Memória de Curitiba).

Após mais de um século de existência, a Rua XV ainda não havia adquirido sua característica de calçadão, já que mesmo com o Plano Agache de 1943, quando Curitiba legitimamente inicia seu planejamento urbano, ainda não se pensava nessa possibilidade. Com o Plano Diretor da Cidade em 1970, muitos aspectos que não haviam sido considerados no plano anterior passam a fazer parte da nova pauta, inclusive algumas medidas do Plano Agache são repensadas. Um desses novos planos era a Rua XV de Novembro, que vinha sendo castigada pelo excesso de veículos, o que expulsava diariamente mais e mais pedestres de seu espaço. O asfalto, que outrora atraia o uso popular por promover o footing, agora era atrativo apenas para o fluxo de automotores, inibindo o uso do pedestre que se repelia por conta da poluição sonora e química dos escapamentos.

Nesse contexto é perceptível como essa imagem de rua antes agradável para o uso do pedestre vai tomando um novo caráter a partir do uso intensivo do carro, imprimindo assim um novo uso e enfraquecendo o uso anterior - é o espaço urbano dando sinais de potencial “educador”, como se aquela imagem caótica que passava a ser impressa pelo uso do carro viesse “deseducar” o pedestre no seu anseio pelo espaço público. O espaço e seu contexto “sintático"”, por mais que não tivesse ainda sofrido qualquer alteração, com o decorrer do tempo e da evolução tecnológica, passa a carregar em si outro contexto "semântico", diferente daquele pelo qual teve sua origem. O asfalto que antes era palco para o uso do pedestre, que atraia o “footing”, passa a repeli-lo com o uso do automóvel, potencializando uma nova forma de apropriação que antes não havia sido considerada. Essa simbiose entre intenção projetual e apropriação do usuário a posteriori muito carrega o

\footnotetext{
${ }^{3}$ Entende-se por contexto sintático de projeto as questões físicas do mesmo, palpáveis, visíveis, como a funcionalidade espacial, a forma em si.

${ }^{4}$ Considera-se contexto semântico o sentido filosófico projetual, a intenção abstrata daquele que projeta o espaço, as sensações e as “mensagens” por trás das formas projetadas.
} 
aspecto efêmero do espaço construído em si, e demonstra com clareza que é na significância do mesmo que esse se faz pertinente, sendo assim elemento "educador" do cidadão que se apropria daquele lugar.

Com Jaime Lerner na prefeitura, o plano de devolver para o pedestre a Rua XV foi se tornando realidade, apesar da opinião contrária tanto por uma parte da imprensa quanto, em especial, dos comerciantes. Esses que acreditavam que tirar o carro da rua era assinar o atestado de óbito da mesma já que, na visão deles, essa atitude iria diminuir o fluxo de pessoas. O plano então era recuperar a antiga Rua das Flores, trazendo cultura, lazer, espaços de estar, a fim de reviver a memória do curitibano, atraí-lo novamente para o centro da cidade: a rua como extensão da sala de casa, onde o usuário pudesse conviver em sociedade sem precisar se preocupar com qualquer tipo de poluição. O projeto ganha um caráter de “reeducação” do cidadão para o retorno ao centro, a partir da requalificação do espaço urbano, por intermédio de um projeto que quer retomar a antiga semântica daquele espaço a partir de uma nova ordem sintática. O que para muitos era uma ideia inovadora, na realidade apenas se estava retomando o seu caráter inicial, porém, com outras ferramentas e instrumentos, já que a sociedade já não era a mesma e tinha necessidades diferentes (BARZ; BOSCHILIA; HLADCZUC; SUTIL, 1997).

Ou seja, antes mesmo do processo de pedestrização em si, já fica evidente o rebatimento simultâneo entre espaço urbano e demandas humanas, e como ao mesmo tempo essas mesmas demandas humanas irão culminar em um espaço urbano com determinadas características. Não existe sentido único nesse processo, e sim um fluxo dialético entre demandas construídas socialmente e espaço construído arquitetônica e urbanisticamente, capaz de educar e reeducar gerações.

\section{O FATO DA PEDESTRIZAÇÃO}

A transformação da Rua XV de Novembro, via que corta a cidade de leste à oeste desde o início de sua história e que vinha sofrendo com o acúmulo de automóveis e a consequente poluição sonora/visual/atmosférica, aconteceu no primeiro mandato do Prefeito Jaime Lerner que, no caso, foi nomeado por se tratar de um período de Regime Militar, iniciado em 1964, perdurando até 1985.

O prefeito arquiteto e urbanista (e engenheiro) já participava de muitas das discussões de prefeitura como membro de uma comissão participante na elaboração do Novo Plano Diretor de Curitiba (1966), e que com o seu novo cargo se viu numa posição favorável a colocar em prática o que vinha sendo discutido há muito tempo (Entrevista Instituto Jaime Lerner, 2009). 
Sua nomeação ocorre em 1971, ano que marcaria o início da "Era Lerner”, conhecida como um divisor de águas na história de Curitiba. Nesse momento o estigma de cidade sem carisma começa a ser apagado, e os novos codinomes de Cidade Modelo, Cidade Sorriso começam a receber investimentos (Entrevista Instituto Jaime Lerner, 2009). Seriam novas imagens sendo impressas no imaginário daquela população a partir de um contexto social-histórico-temporal que viria perdurar talvez até os dias de hoje.

A primeira obra marcante do primeiro mandato é a transformação da caótica Rua XV de Novembro em um calçadão destinado exclusivamente ao pedestre. Apesar de ser um projeto elaborado anteriormente durante dois anos, cujas bases eram pesquisas internacionais que provavam o melhoramento urbanístico e social resultantes de ações semelhantes já aplicadas, num primeiro momento uma parte da população se posicionou de forma contrária à ideia, bem como grande parte dos comerciantes da própria rua (Entrevista Instituto Jaime Lerner, 2009).

Confiando que o projeto teria aprovação da população e do comércio depois que a obra estivesse pronta, o prefeito em exercício decide, após argumentar com a parte técnica responsável pela obra, que em setenta e duas horas grande parte da mesma estaria concluída (Entrevista Instituto Jaime Lerner, 2009). A fim de evitar problemas jurídicos, como o embargo de obra que poderia ser feito a pedido dos comerciantes, a obra teve inicio após o horário comercial, 18 horas, da sexta-feira dia 19 de maio de 1972, escolha que permitiu um final de semana inteiro de obras ininterruptas. O planejado foi então executado, e na segunda-feira comércio e usuários se depararam com uma Rua XV de Novembro calçada de petit-pavet, com bancos, árvores e flores plantadas, faltando apenas a instalação de postes de iluminação (Fundação Cultural de Curitiba, 1992).

A prefeitura buscou uma forma menos burocrática e mais ágil para conseguir colocar um projeto que geraria inúmeras controvérsias. Ou seja, apesar da boa intenção, ficam em aberto algumas questões que acompanham o artigo: o que esse processo controverso traria de mensagem para o cidadão? Qual o aprendizado que se pode tirar da postura do prefeito? É preciso entender os diferentes atores e as diferentes intencionalidades que se articularam naquele espaço-tempo para permitir que a pedestrização acontecesse, e para isso se faz necessária a metodologia de analise da Teoria SCOT. 


\section{ANÁLISE SCOT SOBRE A PEDESTRIZAÇÃO}

\section{A Posição dos Militares}

O Brasil vinha passando por um dos períodos mais complicados de sua história do ponto de vista político, o Regime Militar. Durante esse período, pouco se podia opinar sobre decisões políticas e/ou questões que causassem alguma discussão ou comoção popular.

Nesse sentido, para o sistema ditatorial, era interessante que existissem outros motivos para os quais a população pudesse se atentar, que não discutir a forma com a qual o país num âmbito federal era comandado - contanto que esses motivos não causassem tumultos com repercussão maior do que uma escala local. Nesse sentido, o contexto político já explicitaria uma conotação de controle da população, a fim de que essa se “ocupasse” de outros assuntos que não a política em si. Sendo assim, a Prefeitura de Curitiba poderia contar com o silêncio por parte do governo federal, o que era positivo para a tomada de decisões, que se mantinha no Município e, no máximo, na região próxima. Com o controle militar sobre os meios de comunicação, devido à censura, a prefeitura também contava com uma mídia aparentemente imparcial, que induziria direta ou indiretamente a posição do governo para a população. Ou seja, mais uma vez era aquele espaço-tempo especifico que permitia que determinados posicionamentos burocráticos fossem considerados ou não, promovendo assim a efetivação de vias alternativas para a reformulação do espaço urbano.

A flexibilidade de interpretação para o caso da pedestrização da rua XV de Novembro é clara, já que essa ação, apesar de positiva para a cidade num contexto ampliado, para um governo militar era também uma forma especialmente interessante para atrair à atenção e a opinião pública para outro assunto que não a ditadura. Esse relevante grupo social, apesar de não atuar diretamente ou na obra ou no projeto, contribui para que essa fosse efetivada, devido ao seu interesse por trás da mesma. Assim, a obra adquire um contexto amplo, para além da própria intervenção urbana.

\section{A Posição da Prefeitura}

Para a prefeitura, aquele era o momento oportuno para grandes mudanças, que viriam marcar tanto a Cidade de Curitiba quanto o currículo daqueles envolvidos no processo de desenvolvimento urbano da cidade. Muito além de pensar a cidade como um todo - desde as melhorias advindas do Plano Agache (1943), Plano Diretor (1966) e durante a "Era Lerner" (19711975 como período do primeiro mandato durante o regime militar e posteriormente entre 1989-1992 já em período democrático) - devemos refletir sobre os efeitos positivos que aquele raciocínio revolucionário traria para os que estavam no poder ou que estavam participando dessas mudanças: num período de política conturbada, quem se mostrasse diferente daquilo que a população estava 
acostumada e inovador do ponto de vista de gestão e de projetos, ganharia a simpatia do povo e, se não trouxesse problemas para o Regime Militar, teria o seu apoio.

Além desse aspecto, a posição da prefeitura na mídia se mostrou aparentemente bastante responsável e compreensiva, sempre buscando justificar suas escolhas e posicionamentos, por mais que as opiniões ali contidas, nestes mesmos veículos midiáticos, não fossem tão favoráveis às suas posturas.

Tais posicionamentos revelam o amplo contexto no qual o projeto se dava, onde um prefeito nomeado e que não era conhecido pela população buscava visibilidade; uma cidade que vinha sofrendo com problemas urbanos na sua área central devido ao acúmulo de carros; um período de ditadura militar que não permitia grandes contestadores ou formadores de opinião que não estivessem à favor do regime. Assim, como grupo social relevante, a Prefeitura Municipal de Curitiba consegue dentro de uma flexibilidade de interpretações, enquadrar a proposta de calçamento em seus interesses diversos: políticos e urbanos.

\section{A Posição da Classe dos Arquitetos}

Com um prefeito arquiteto, a sua classe se coloca em defesa da Prefeitura de Curitiba, bem como o arquiteto responsável pelo projeto da Rua XV de Novembro, Abraão Assad. Enfatizando esse posicionamento, são convocados arquitetos internacionais para opinar a favor das mudanças, bem como de profissionais locais, a fim de convencer a população que a mudança, apesar de radical e de quebrar costumes, traria apenas benefícios à longo prazo.

Estou surpreendido com as medidas de Curitiba em fazer voltar aos pedestres o centro da cidade (NAMMAR, MITRI, arquiteto libanês, Gazeta do Povo, 20.04.1972).

Curitiba tem tomado atitudes programáticas cujos conceitos já são defendidos há muitos anos na União Soviética (YOURL, BRAKC, arquiteto russo, Gazeta do Povo, 20.04.1972).

(...) facilita o comercio e permite maior convívio humano e elimina ruídos e acidentes naquelas vias (LUBEN, TONEV, arquiteto húngaro, Gazeta do Povo, 20.04.1972).

Com o projeto, Curitiba ganha visibilidade internacional, o que para a classe de arquitetos era interessante, já que isso estaria acontecendo a partir de conceitos arquitetônicos e urbanísticos. Assim sendo, a visibilidade não acontecia apenas para a cidade, prefeitura e prefeito, mas também para os profissionais da área, que viam uma oportunidade de também ganhar visibilidade, estabilidade e maior valorização - nacional e internacional. 
A classe dos arquitetos, então, se mostra um relevante grupo social dentro do amplo contexto no qual a obra emergia, já que a flexibilidade interpretativa mostra que a ação política e urbana também atuava como um forte motor para o crescimento e valorização da classe profissional em questão. Ou seja, não era apenas a melhoria do aspecto urbano e social que aconteceria a partir da mudança espacial proveniente do processo de pedestrização, mas também viria valorizar o trabalho de uma classe.

\section{A Posição da Mídia}

Como comentado anteriormente, fica clara a interferência da censura nas edições do jornal que foram avaliadas para a presente análise. Pouco se fala do que é nacional ou local: o foco se mostrou, em grande parte, direcionado para os acontecimentos no exterior. Porém, quando o assunto transcorria sobre a obra de calçamento da Rua XV de Novembro, a posição do jornal era passar a notícia sem se posicionar com firmeza, apesar de se inclinar para um posicionamento favorável à Prefeitura.

Após a entrega da obra, notou-se certa diferença entre teor do que era noticiado antes da obra, já que, além de elencar diversas opiniões positivas em relação à mesma, se falava também na opinião contrária às mudanças provenientes dos comerciantes. Apesar dessa introdução de críticas à obra, no mesmo período foi encontrada na Coluna do Leitor uma carta com a posição favorável de um curitibano que mandara sua opinião ao jornal.

Considerando a teoria SCOT, o amplo contexto no qual a obra se dava mostrou uma mídia tímida devido ao período militar, porém, é possível constatar que sua intenção nunca foi a de questionar o que vinha sendo planejado e efetuado pela prefeitura, e sim convencer a população daquilo que se via como positivo diante da ação para a cidade - por mais que realmente fosse. Não foram encontradas opiniões contrárias publicadas até que a obra fosse entregue à população, o que possibilita uma flexibilidade quanto à interpretação: uma população que realmente não se mostrava contra, ou um jornal instruído para fazer com que a população pensasse que a maioria era à favor, a fim de colaborar com a aceitação do projeto? Tal dicotomia viria favorecer grupos sociais relevantes, e assim também acalmaria outros contrários. As opiniões encontrariam o que a teoria considera como closure, caracterizando o encerramento de um embate de ideias; a mídia caracterizada no caso como o Jornal Gazeta do Povo é determinante nesse processo. Assim sendo, considerando um debate pouco democrático em relação ao tema, como aquele contexto espaçotempo propiciava, percebe-se a tendência ao comodismo de uma população em relação ao que a mídia “dizia”. Então, será que o espaço-tempo específico seria responsável por isso, devido à 
censura e ao regime militar ou a população já encontrava dificuldade para discernir aquilo que era fato daquilo que era posicionamento de um canal de mídia?

\section{Posição da População}

Apesar de não ser evidente e comprovada, as noticias mostraram que a opinião da população anunciava ansiedade em relação à mudança, e não uma posição contrária à obra. No período estudado, apenas um habitante de Curitiba opina sobre o assunto diretamente, numa carta direcionada ao jornal Gazeta do povo:

É inacreditável que certos comerciantes curitibanos, localizados no trecho da Rua XV de Novembro que hora esta sendo embelezada pela Prefeitura Municipal de Curitiba, venham se opor casmurramente, ao belo plano de obras encetado por ordem do Prefeito Municipal. Basta-se conhecer Rio, São Paulo, Porto Alegre, para ser testemunha que as capitais brasileiras a muitos anos mantém muitas de suas vias públicas interditadas à circulação normal de veículos, tais como rua do Ouvidor, Gonçalves Dias, Rua Direita, Rua da Praia em Porto Alegre e tantas outras. E sem qualquer embelezamento público. Assim é estranhável que se oponham de uma maneira tão provinciana ao embelezamento paisagístico de uma das nossas principais artérias. A guisa de cooperação, sugerimos ao conceituado e mais tradicional jornal curitibano, que é a Gazeta Do Povo, que promovesse uma enquete junto ao povo curitibano para ouvir a opinião sobre o assunto. É Óbvio, ${ }^{*}$, que a implantação do "boulevard" curitibano jamais virá trazer prejuízos ao comercio local. As razões evocadas por alguns comerciantes chega às raias de ${ }^{* 6}$ e de acentuado sabor provinciano...Há que se convir ainda que acima do interesse de meia dúzia de comerciantes está o interesse de uma esmagadora maioria de munícipes curitibanos que de igual modo, pagam também seus impostos municipais; mas que contam com a satisfação de ver o erário arrecadado destinado ao desenvolvimento da nossa cidade. Em todas as cidades brasileiras sobrepaira sempre a opinião negativista de poucos e “inesclarecidos” munícipes que não chega a "obstacularizar” o desenvolvimento de suas cidades. É o caso de nossa Curitiba. (...) (Coluna do Leitor, Gazeta do Povo, 27 de Maio de 1972).

Não se pode avaliar toda uma população a partir da opinião de um único cidadão, principalmente se considerando um período de censura e de grande indução midiática. Este amplo contexto mostra que o grupo social relevante em questão, que seria a população, apesar de ser o

\footnotetext{
${ }^{5}$ Trecho ilegível devido à qualidade da microfilmagem.

${ }^{6}$ Trecho ilegível devido à qualidade da microfilmagem.
} 
grande foco da obra, sua opinião como massa pouco aparece na mídia, o que provoca mais uma nuance de flexibilidade interpretativa: seria o caso de uma população com opinião contrária - ou até à favor - mas que não quer aparecer devido ao período histórico? Seria um artifício jornalístico da própria prefeitura em não mostrar a opinião contrária da população e tentar reverter a sua posição com essa censura? Ou realmente a população não se opunha? O que esse contexto de espaço-tempo seria capaz de imprimir em sua população e em consequência também no seu espaço urbano e suas diferentes apropriações?

Mais uma vez a teoria SCOT é capaz de caracterizar o fenômeno, já que a população passa por um processo de estabilização de um posicionamento que aparentemente se mostra global dentro desse grupo social relevante, a fim de que a ideia se constituísse num grupo coeso capaz de enfrentar as posições contrárias dos outros grupos sociais que partilham o mesmo processo. Se o jornal publica com ênfase apenas a posição favorável, o que se pode dizer num contexto amplo: seria verídico ou construído esse posicionamento?

\section{Posição dos Comerciantes}

O Posicionamento por parte dos comerciantes do trecho da Rua XV de Novembro que recebe o calçadão em frente à suas lojas foi o grupo social relevante que mais se mostrou contrário à proposta. É fato conhecido pela população contemporânea o posicionamento conservador desses comerciantes na época. Porém, apenas com a pesquisa feita diretamente na Gazeta do Povo, pode-se entrar em contato com a opinião escrita desses sobre essa primeira e revolucionária operação urbana curitibana:

As obras fundamentais, realizadas pela Força e Luz e Telepar, apesar dos contratempos, nós aceitamos porque são benéficas à população. Entretanto, desde que a Rua XV foi fechada, sofremos as negativas consequências do ato; se antes era difícil o freguês vir até aqui, quando não encontrava lugar para estacionar, que dirá agora que não pode passar com seu veículo pela rua. Vou exemplificar com os fatos: numa visita de representantes nossos ao prefeito Jaime Lerner, levamos-lhe o quadro comparativo de janeiro do ano passado e o do mesmo período desse ano. Nele acusávamos uma queda de vendas de $40 \%$ sem considerarmos a desvalorização da moeda. Agora, além de nossas negras perspectivas o prefeito demonstra não ter confiança nas obras que empreendeu. Que administração é essa que não tem previsão de seus atos pois promete desmanchar a obra se ela não der certo? Ou foi mais uma maneira de nos enrolar? (Sr. Tomé, Proprietário do Magazine dos Enxovais, Gazeta do Povo, 23 de Maio de 1972). 
Este trecho vai se transformar num outro local onde irão se concentrar maloqueiros e vendedores de bilhetes de loteria. Além disso, a existência de bancos e a colocação de mesas e cadeiras nas calçadas, defronte aos bares, impedirá que senhoras e senhoritas por aqui passem, prejudicando o comércio em geral e o nosso. Ninguém vai querer passar e ouvir comentários desairosos daqueles que ficarem tomando aperitivos. Curitiba ainda não comporta um “Centro Comercial” desses moldes (Sr. Bub, Gazeta do Povo, 23 de Maio de 1972).

Tais argumentações mostram que os comerciantes, aparentemente em sua maioria, foram incapazes de vislumbrar possibilidades positivas a partir da proposta da Prefeitura, além de se apegarem aos conceitos preestabelecidos que já funcionavam para eles, mas que não vinham respondendo às demandas urbanas daquele novo espaço-tempo que vinha se configurando. $\mathrm{O}$ excesso de carros na região central complicava a circulação dos habitantes, tanto para aqueles que tinham seus automóveis quanto os que andavam a pé; a poluição na área central era crescente, devido ao automóvel que ainda não tinha agregado em seu projeto mecânico preocupações quanto ao barulho do motor ou à poluição gerada por seu escapamento. Ao contrário, na visão dos comerciantes, o prefeito que, talvez por ser arquiteto urbanista, já conseguia identificar possíveis soluções para problemas futuros, parecia estar se opondo à própria população e ao setor de comercio, que não conseguiam compreender essas novas variáveis.

Apesar de ser uma ideia majoritariamente entendida como positiva - lembrando aqui que existem interpretações flexíveis quanto a isso - para os comerciantes o calçamento era sinônimo de problemas nas vendas e em consequência queda nos lucros, diminuição da clientela e possível fechamento dos estabelecimentos, já que a prefeitura havia tomado atitudes anteriores que não vinham agradando à classe comerciante, como a implantação do Proparq ${ }^{7}$ em algumas quadras que posteriormente seriam transformadas em calçadão (Gazeta do Povo, 27 de Maio de 1972).

\footnotetext{
${ }^{7}$ O Proparq foi uma medida paliativa para tentar amenizar o trânsito na região central, determinando a área da Boca Maldita como estacionamento temporário, que acabou culminando em um ainda menor fluxo de clientes nas lojas da região, alarmando o setor do comércio em relação aos possíveis desdobramentos negativos da pedestrização da Rua XV de Novembro.
} 


\section{Posição dos Técnicos Envolvidos}

O corpo técnico cuja opinião foi encontrada no Jornal Gazeta do Povo, não mostrava entusiasmo em relação à obra. Talvez por se tratar de um raciocínio puramente técnico, esse se concentrava em discutir os problemas que a obra vinha trazendo durante sua execução, e não os possíveis benefícios posteriores à sua instalação.

Segundo o funcionário Luiz Armando* ${ }^{8}$, a obra do calçamento da Rua XV de Novembro "não compensaria os problemas que suscita sendo infindáveis as reclamações de usuários, principalmente no que se refere a segurança dos $*^{9}$, registrando-se dezenas de furtos e $*^{10}$ em demonstração de que a guarda ${ }^{11}$ não é observada” (LUIZ ARMANDO, Jornal Gazeta do Povo, 27 de Maio de 1972). Apesar de não ser possível a leitura nítida da reportagem na qual essa opinião foi publicada, a posição do técnico pode ser entendida com relativa clareza.

Não foi possível encontrar nenhum outro relato direto de um técnico quanto à obra, porém, em entrevista no Instituto Jaime Lerner em 2009, o Ex-Prefeito fala a respeito das longas conversas que teve com o setor de obras a fim de que o calçamento acontecesse rapidamente. Ele precisou convencer tais profissionais de que a obra seria positiva para a cidade (Entrevista Instituto Jaime Lerner, 2009).

Apesar de sua ação direta em relação à obra, os técnicos envolvidos não se enquadrariam em um dos relevantes grupos sociais que participaram do processo tecnológico (processo pelo qual acontece o calçamento da Rua XV de Novembro) de instalação do calçadão em questão, já que no contexto amplo não participam da flexibilidade interpretativa, nem causam estabilização ou fechamento no significado do artefato, mesmo sendo responsáveis por sua conclusão em 72 horas.

\footnotetext{
${ }^{8}$ Trecho ilegível devido à qualidade da microfilmagem.

${ }^{9}$ Trecho ilegível devido à qualidade da microfilmagem.

10 Trecho ilegível devido à qualidade da microfilmagem.

11 Trecho ilegível devido à qualidade da microfilmagem.
} 


\section{CONCLUSÃO}

A escolha pela teoria SCOT para desconstruir e compreender o processo de instalação da Rua XV de Novembro e a subsequente, para não dizer simultânea construção da sua imagem para os diferentes atores envolvidos no mesmo, conhecida como primeiro calçadão exclusivo para pedestres no Brasil, é essencial para que fossem identificados atores, posicionamentos, relevâncias e contextos do processo ${ }^{12}$. A cidade é vista como manifestação de uma construção social de diferentes atores com variadas intenções, todas compondo coletivamente um meio a ser desfrutado esteticamente, e esse movimento também é tido como momento de ensino/aprendizagem, agora para além do espaço escolar tradicional. A riqueza desse processo ainda se dá quando consideramos além da construção imagética para os diferentes atores envolvidos no momento da construção, numa dinâmica horizontal, mas também a dinâmica vertical que possibilita quando tratamos do espaço urbano: aquele espaço permanece como elemento físico (sintático) construído, mas sua identidade (semântica) se mostra mutável, dependente da construção social que o envolve, e que será passada adiante de diferentes maneiras, de acordo com o locutor e interlocutor da sua história.

Com isso fica evidente que essa é contada a partir de posicionamentos possíveis dentro de cada contexto social-histórico-temporal, e que é essa composição que perdura e educa - ou deseduca - uma sociedade. Escolhas tomadas durante recortes de tempo relativamente curtos (como no caso apresentado) são capazes de recompor dinâmicas urbanas e sociais, de distorcer necessidades humanas, e de multifacetar fatos relativamente simples.

No caso estudado, fica clara a relação de poder entre as partes de um sistema no qual os interesses são, no mínimo, diferentes, e que são esses interesses e seus sentidos semânticos, traduzidos em espaços sintáticos que irão estabelecer o sentido icônico daquele momento na história.

Devido à desconstrução feita a partir do caso curitibano, cujo embasamento se deu a partir da compreensão do trabalho sobre o Plano Cerdà de Extensão de Barcelona por Eduardo Aibar e Wiebe E. Bijker, que também se utilizam do método, foi possível perceber diversas controvérsias em todos os processos, e consequentemente múltiplas interpretações para os diferentes

\footnotetext{
12 Não só nesse caso, mas se analisarmos qualquer construção social, precisamos considerar os diversos atores envolvidos no processo, como no caso citado por Dozol (2006), quando essa desenvolve seu livro em torno do pensamento de Rousseau, onde coloca que o ato de educar estaria para muito além de um simples instruir, mas formar para a cidadania, alcançando a ideia de formação do espírito a partir do usufruto da estética em suas diferentes manifestações.
} 
posicionamentos e atores envolvidos. São agentes relativamente semelhantes associados à tantos outros diferentes construindo um processo numa rede complexa, que marca gerações e educa populações à seguir condutas especificas, constituindo uma imagem urbana que se relaciona diretamente com a intencionalidade daquele grupo social especifico tanto quanto o seu espaçotempo permitir dentro do amplo contexto considerado.

A tecnologia aplicada para a criação do artefato, ou seja, o processo pelo qual o contexto curitibano passa a fim de que se construa um calçadão na rua mais movimentada da cidade, apenas se deu devido ao amplo contexto no qual se constituía, já que cada grupo social relevante foi essencial tanto na estabilização quanto no fechamento da significância do artefato. Assim sendo, é possível tornar palpável a relevância dos meios de comunicação mesmo num período de regime militar, bem como a sensibilidade política quanto às oportunidades que se tem em alcançar prestigio a partir de atitudes programáticas, ou seja, situação contextual “educa” também o corpo político a agir de determinada maneira, na medida em que esse agir se transforma em retórica. Contudo, é importante colocar que a construção de significados para aquele processo que se deu nesse contexto apresentado, é um para aquele cidadão contemporâneo ao fato, e pode ser completamente outro para aquela parcela da população que conheceu a estrutura urbana após todo processo, já que os tempos de aprendizagem são outros, apesar do espaço ser o mesmo.

A ideia de projetar um calçadão para a população e atrair as pessoas para a cidade e para o convívio social é apenas uma das inúmeras interpretações possíveis diante do contexto no qual Curitiba se encontrava, e foi esse, devido às articulações midiáticas e políticas, que se estabilizou na memória da cidade, constituindo assim o significado mais profundo e enraizado desse momento histórico no imaginário da população, independente dos interesses variados dos atores envolvidos. Ao final, o que se tem como resultado de todo o processo de requalificação daquele espaço é o próprio sentido semântico da Rua XV de Novembro em seu prelúdio: um espaço para pedestres, desde os tempos do footing até o seu calçamento. Foi então a apropriação do homem, muito mais do que qualquer tecnologia aplicada, que imprimiu significância àquele espaço, e educou as gerações seguintes a valorizá-lo. Ou seja, a rua era calçadão muito antes de sê-lo. 


\section{REFERÊNCIAS}

CURITIBA. Casa da Memória. História de Curitiba. Disponível em: <http://www.casadamemoria.org.br/index_ historiadecuritiba.html>. Acesso em: 15 de Abril de 2012. (atualmente o site foi reatualizado para: <http://www.fun dacaoculturaldecuritiba.com.br>).

Casa Romário Martins. Calçadão, vinte anos depois. Curitiba: Fundação Cultural de Curitiba, 1992, v.19, n. 98.

Casa Romário Martins. Rua XV e o comércio no início do século. Curitiba: Fundação Cultural de Curitiba, 1996, v. 23, n. 113

Fundação Cultural de Curitiba Diretoria de Patrimônio Histórico-Cultural Coordenadoria da Casa da Memória e Acervos Documentais. A Rua XV de Novembro: Patrimônio Cultural do Estado. Curitiba, 1997. Disponível em: <http://www.memorial.mp.pr.gov.br/modules/conteudo/conteudo.php?conteudo=38>. Acesso em: 15 abr. 2012.

Programa de Pós-Graduação em Gestão Urbana da Pontifícia Universidade Católica do Paraná. Entrevista com o Instituto Jaime Lerner. 21 de Setembro 2009. Curitiba. Arquivo Digital. CD-ROM.

DALDEGAN, M.C. Mídia e Política: um estudo sobre o prefeito Jaime Lerner nas primeiras páginas da gazeta do povo em dois períodos distintos (1971-1975 e 1989-1992). In: SEMINÁRIO NACIONAL SOCIOLOGIA \& POLÍTICA, I. Anais... Curitiba: UFPR, 2009. 27p. Disponível em: <http://www.humanas.ufpr.br/site/evento/SociologiaPolitica/GTs ONLINE/GT3/EixoI/midia-e-politica-MilanDaldegan.pdf>. Acesso em: 30 abr. 2012.

DOZOL, M. S. Rousseau. Educação: a máscara e o rosto. 1. ed. Petrópolis, RJ: Editora Vozes, 2006. 102 p.

GAZETA DO POVO. Haverá novidades na nova XV, mesmo fechada. Curitiba, reportagem Edição 12 de Maio de 1972. Acervo Microfilmado Biblioteca Pública do Paraná. Consultado em: 19 nov. 2012.

Volta às origens. Curitiba, reportagem Edição 17 de Maio de 1972. Acervo Microfilmado Biblioteca Pública do Paraná. Consultado em: 19 nov. 2012.

Arquitetos gostam da nova Curitiba. Curitiba, reportagem Edição 20 de Maio de 1972. Acervo Microfilmado Biblioteca Pública do Paraná. Consultado em: 19 nov. 2012.

Propaganda Prefeitura. Curitiba, Edição 20 de Maio de 1972. Acervo Microfilmado Biblioteca Pública do Paraná. Consultado em: 19 nov. 2012.

Nova Rua XV poderia dar lucro às lojas. Curitiba, reportagem Edição 21 de Maio de 1972. Acervo Microfilmado Biblioteca Pública do Paraná. Consultado em: 19 nov. 2012.

Comerciantes Rua XV condenam seu ajardinamento. Curitiba, reportagem 23 de Maio de 1972. Acervo Microfilmado Biblioteca Pública do Paraná. Consultado em: 19 de Novembro de 2012.

População já tem Rua XV. Curitiba, reportagem 27 de Maio de 1972. Acervo Microfilmado Biblioteca Pública do Paraná. Consultado em: 19 nov. 2012.

Coluna do Leitor. Curitiba, 30 de Maio de 1972. Acervo Microfilmado Biblioteca Pública do Paraná. Consultado em: 19 nov. 2012.

GENTILLI, V. O jornalismo Brasileiro do AI-5 à distensão: “milagre econômico”, repressão e censura. Estudos em Jornalismo e Mídia, Florianópolis - Santa Catarina, v. 1, n. 2, p. 88-98, jan. 2004.

LYNCH, K. A Imagem da Cidade. São Paulo: Martins Fontes, 1997. 227 p. 


\section{ANEXOS}

1. REPORTAGEM 12.04.1972

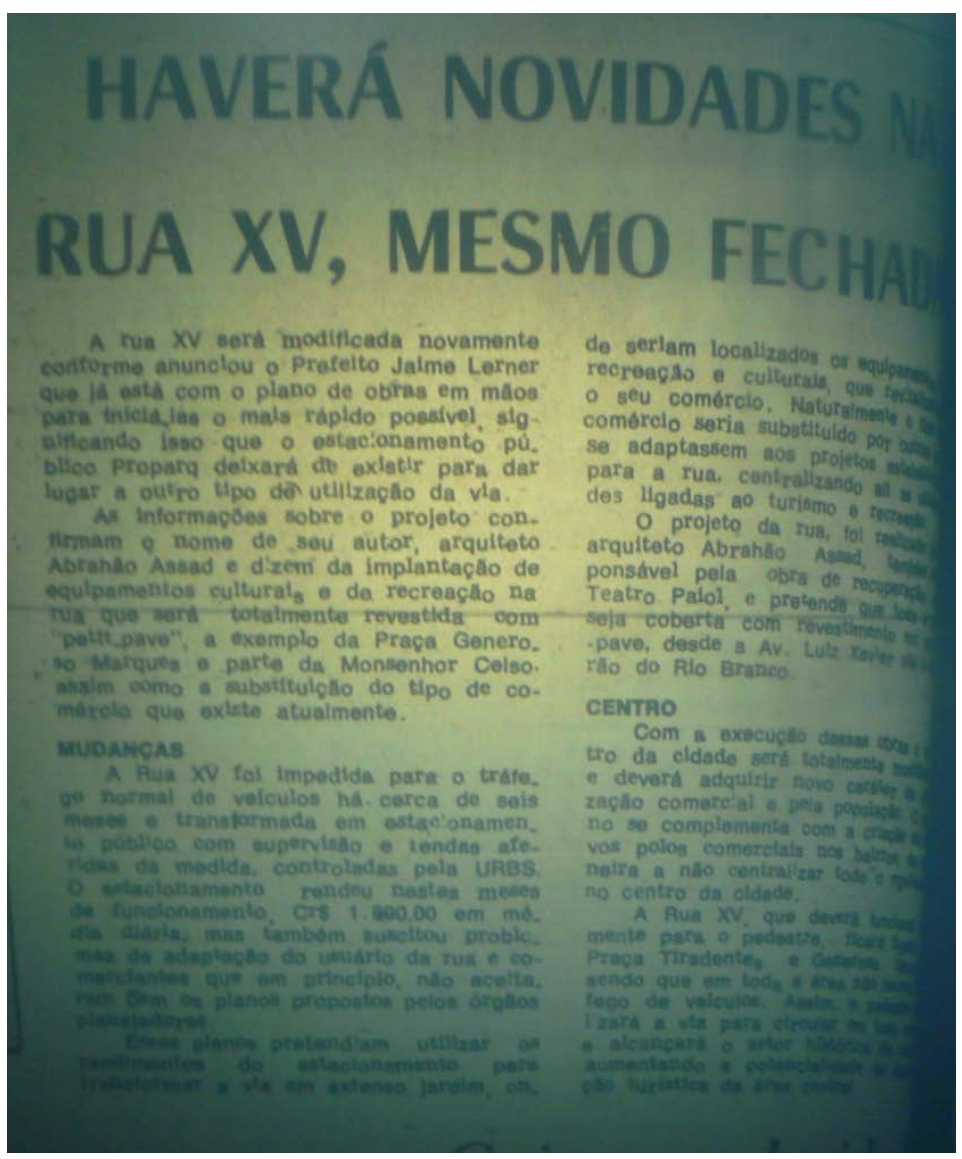

2. FOTO 17.04.1972

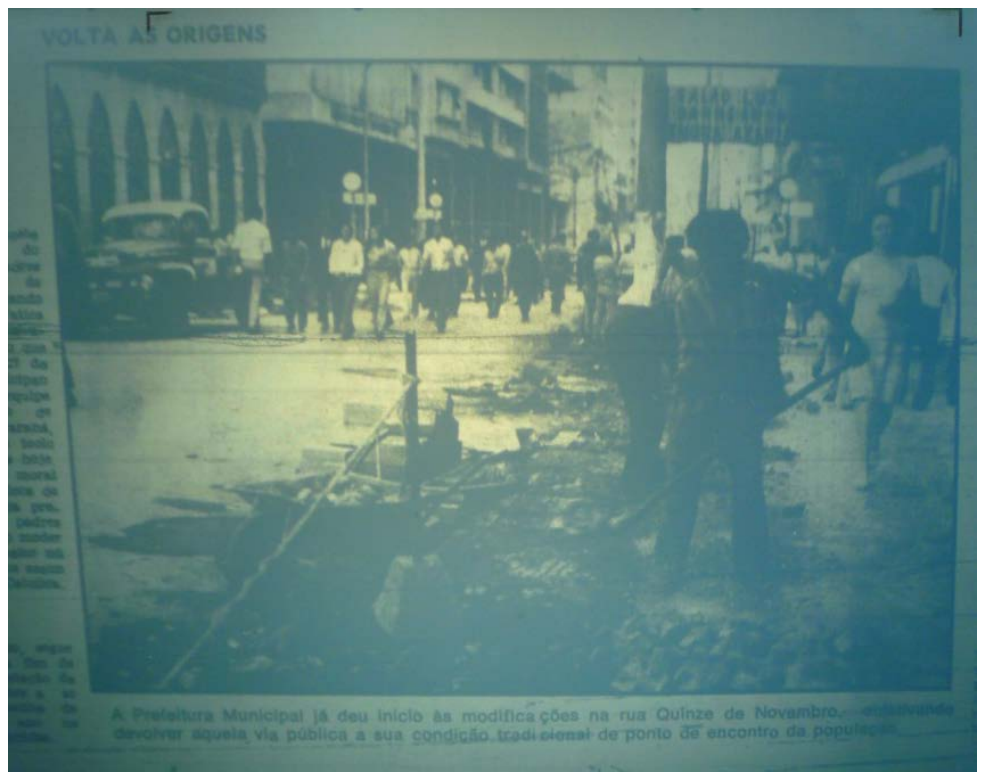




\section{REPORTAGEM20.04.1972}
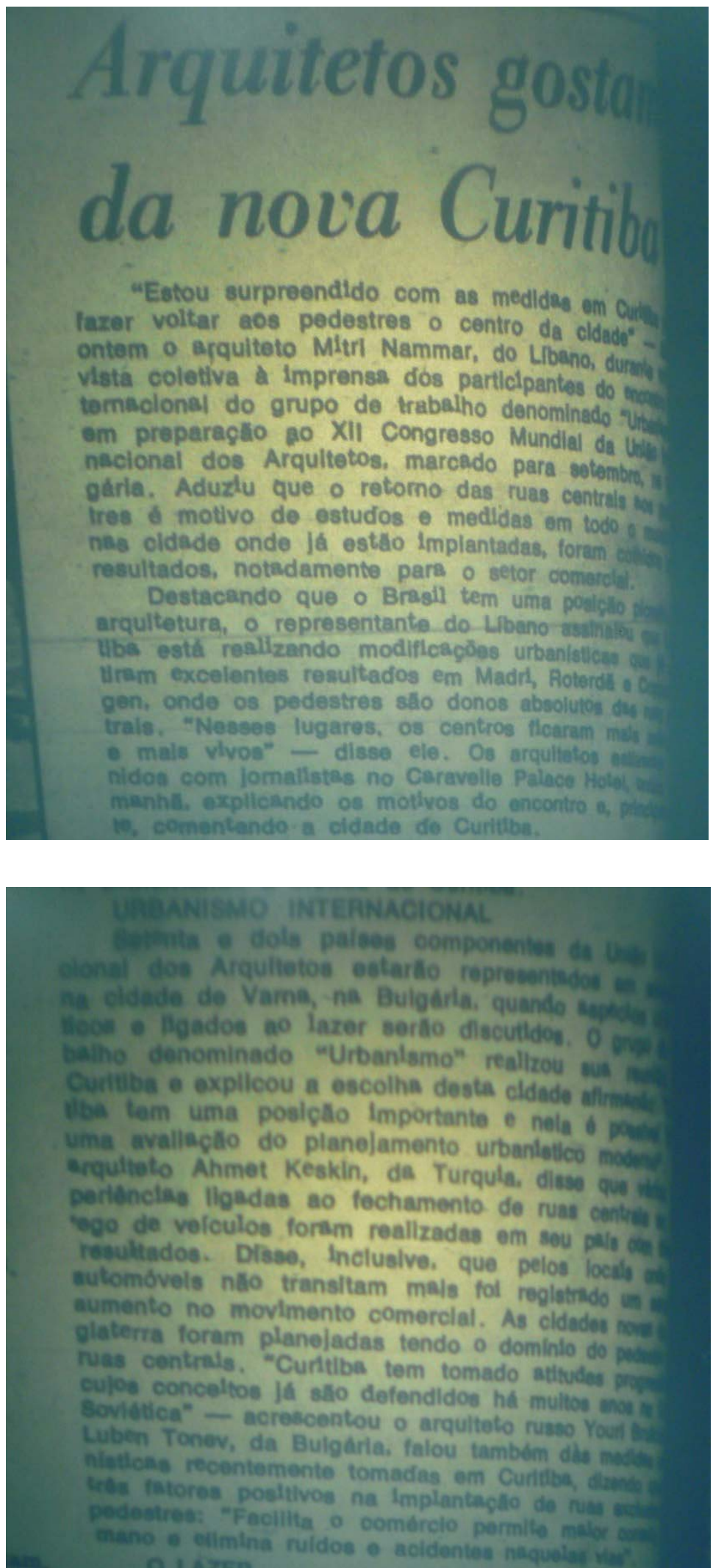


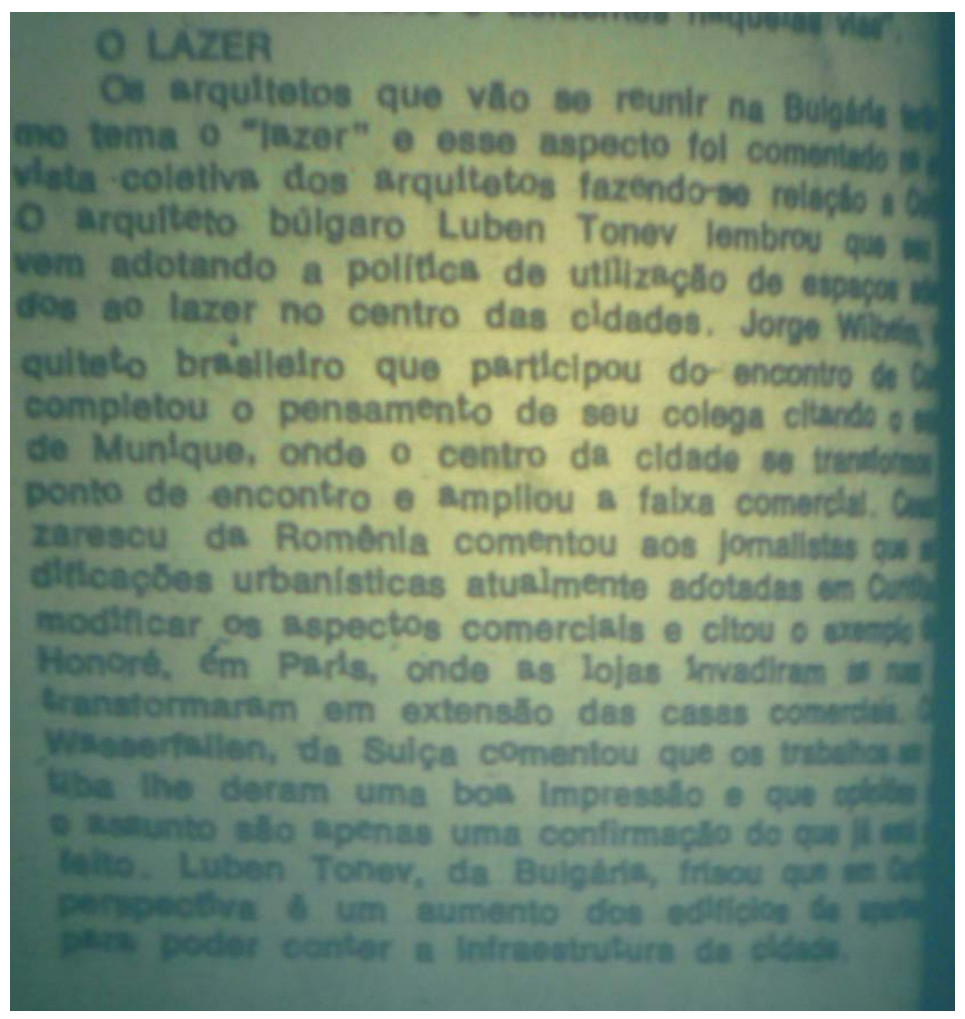

4. PROPAGANDA PREFEITURA 20.04.1972

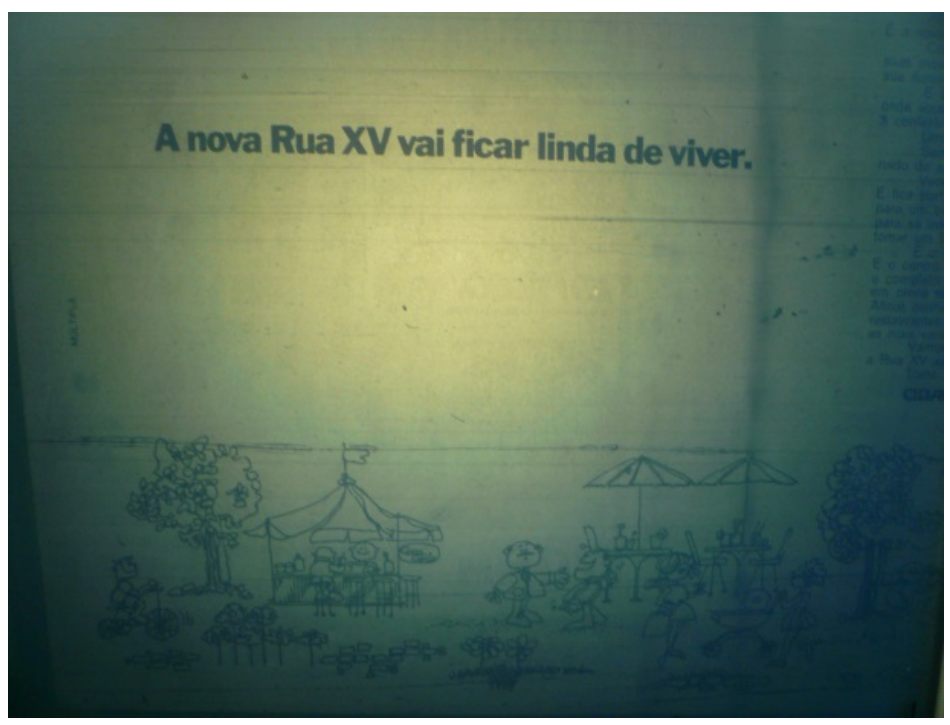




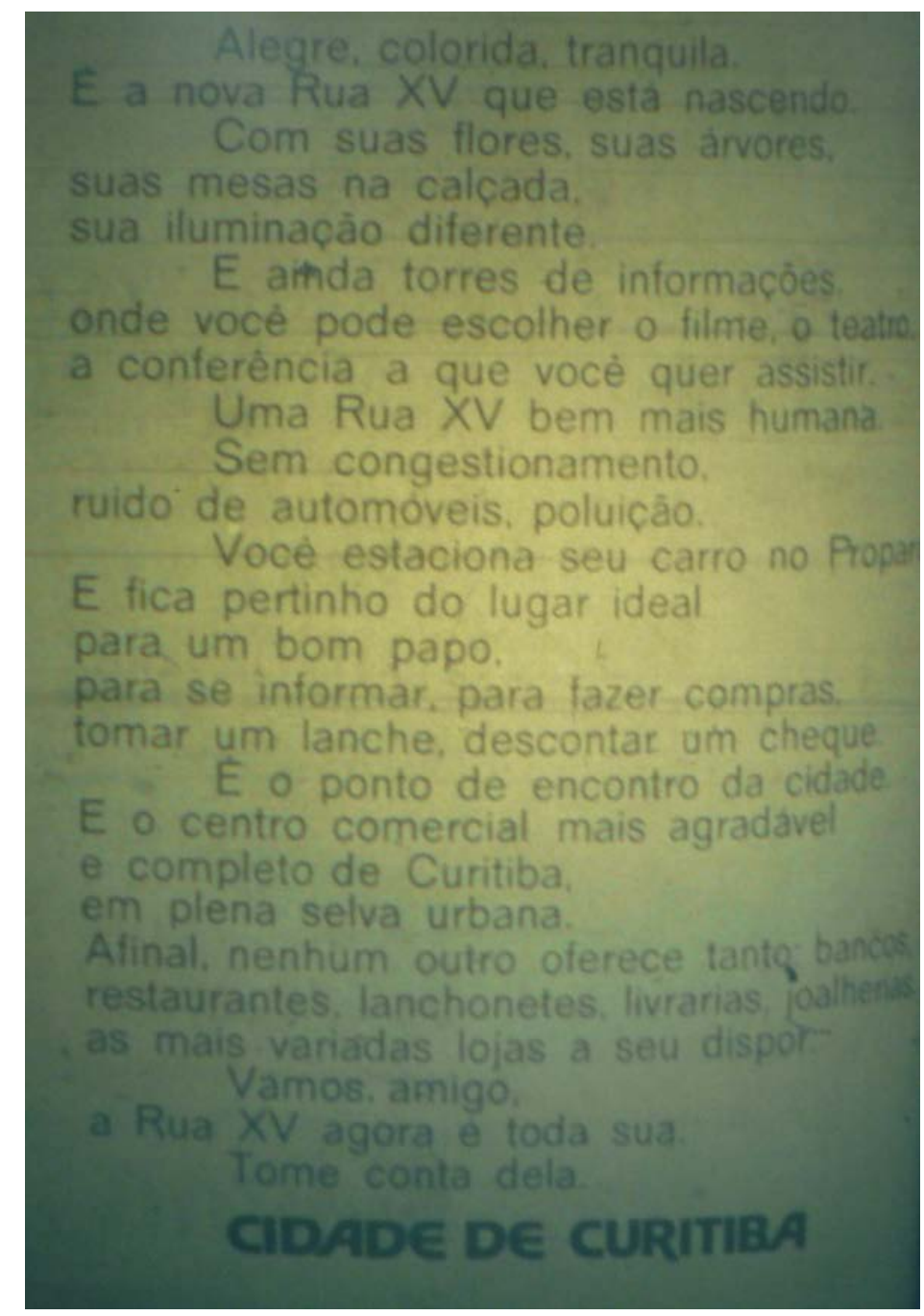

5. REPORTAGEM 21.04.1972

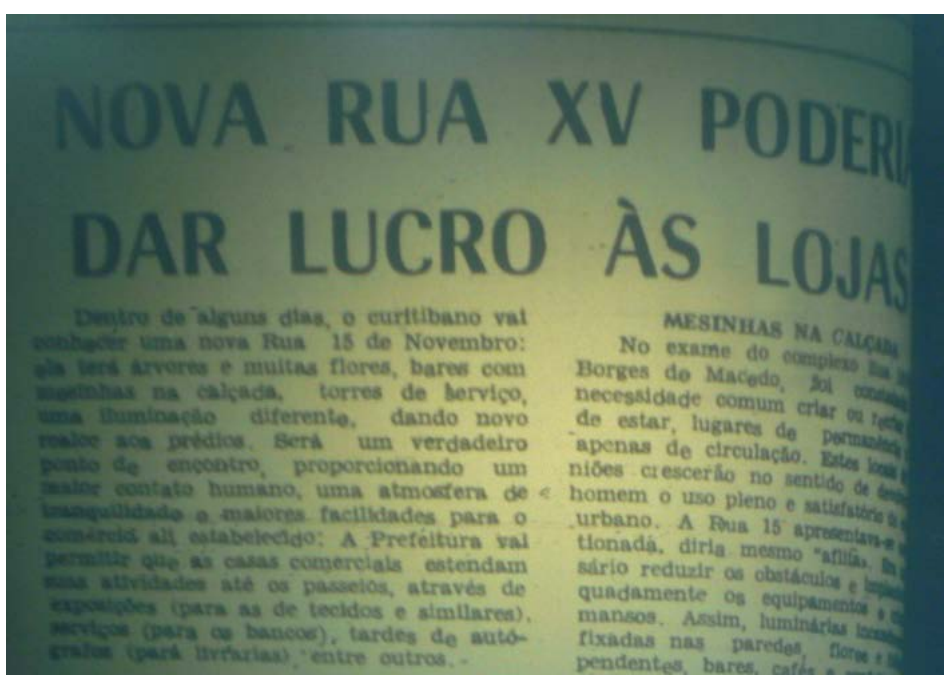



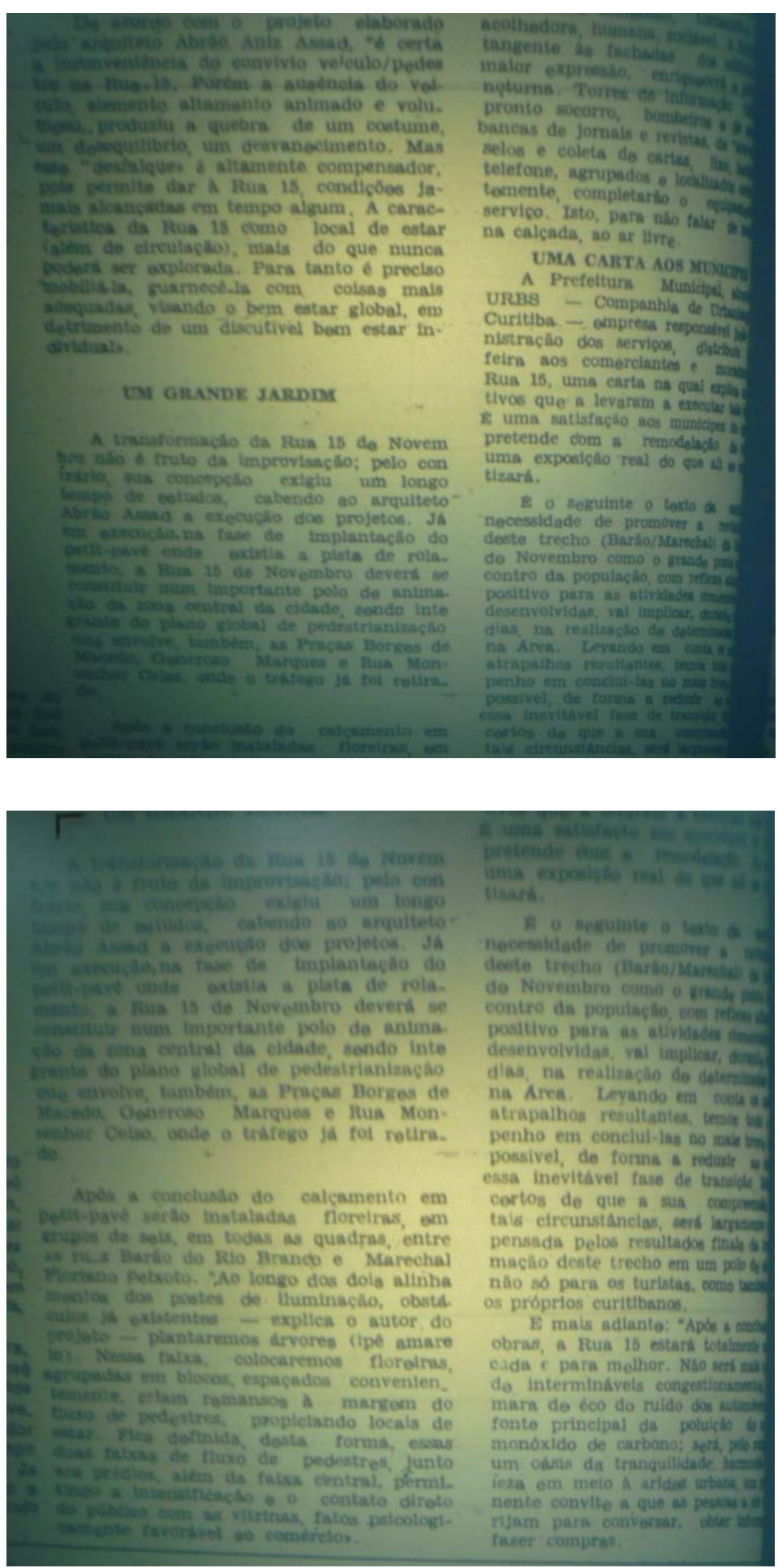
6. REPORTAGEM 23.04.1974
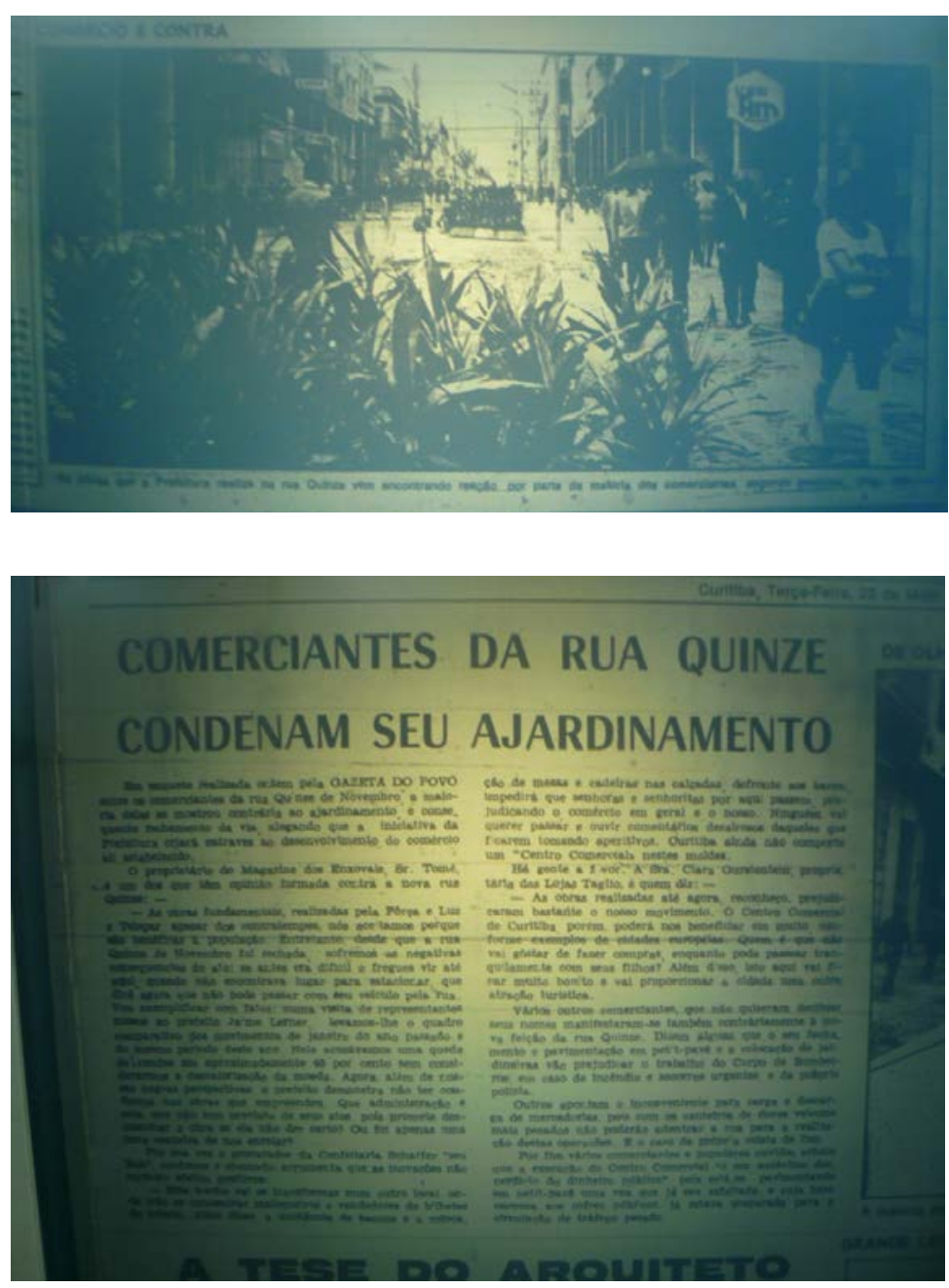

7. REPORTAGEM COMPLEMENTAR 23.04.1974

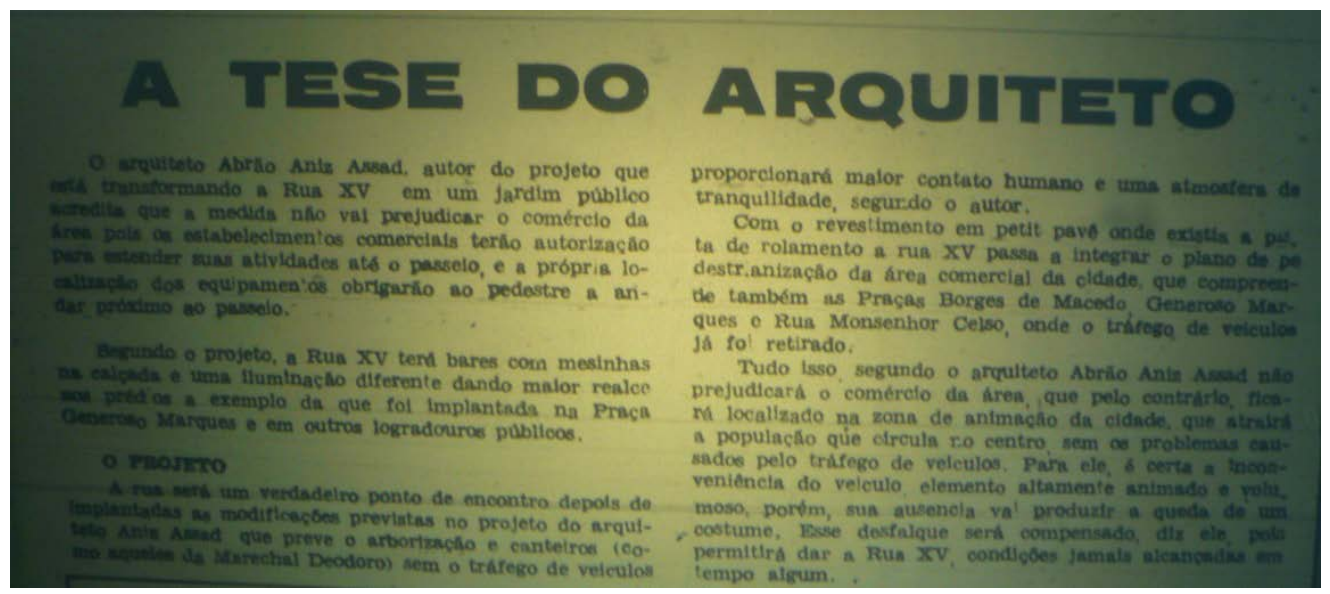




\section{REPORTAGEM 27.04.1974}

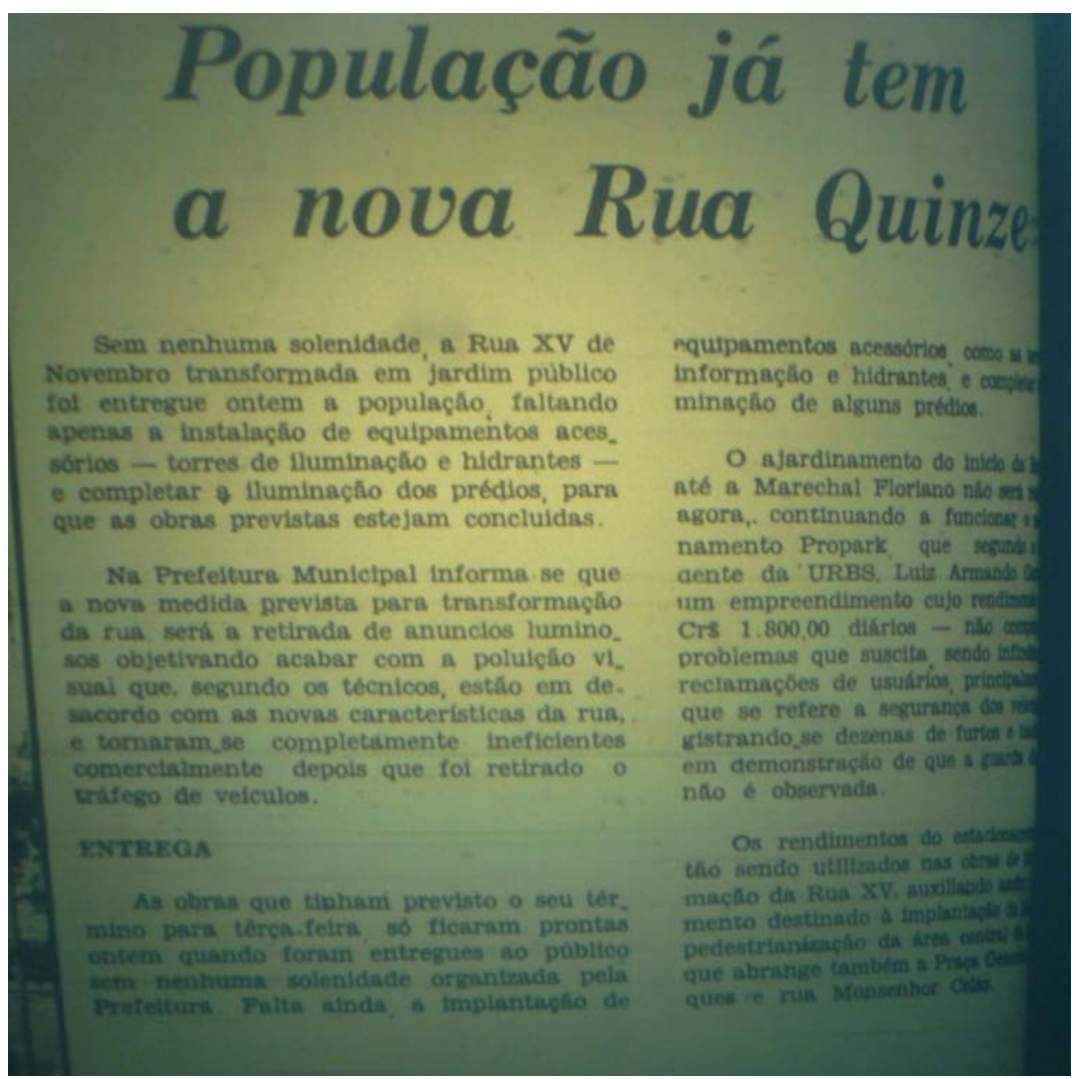

\section{COLUNA DO LEITOR 30.04.1974}
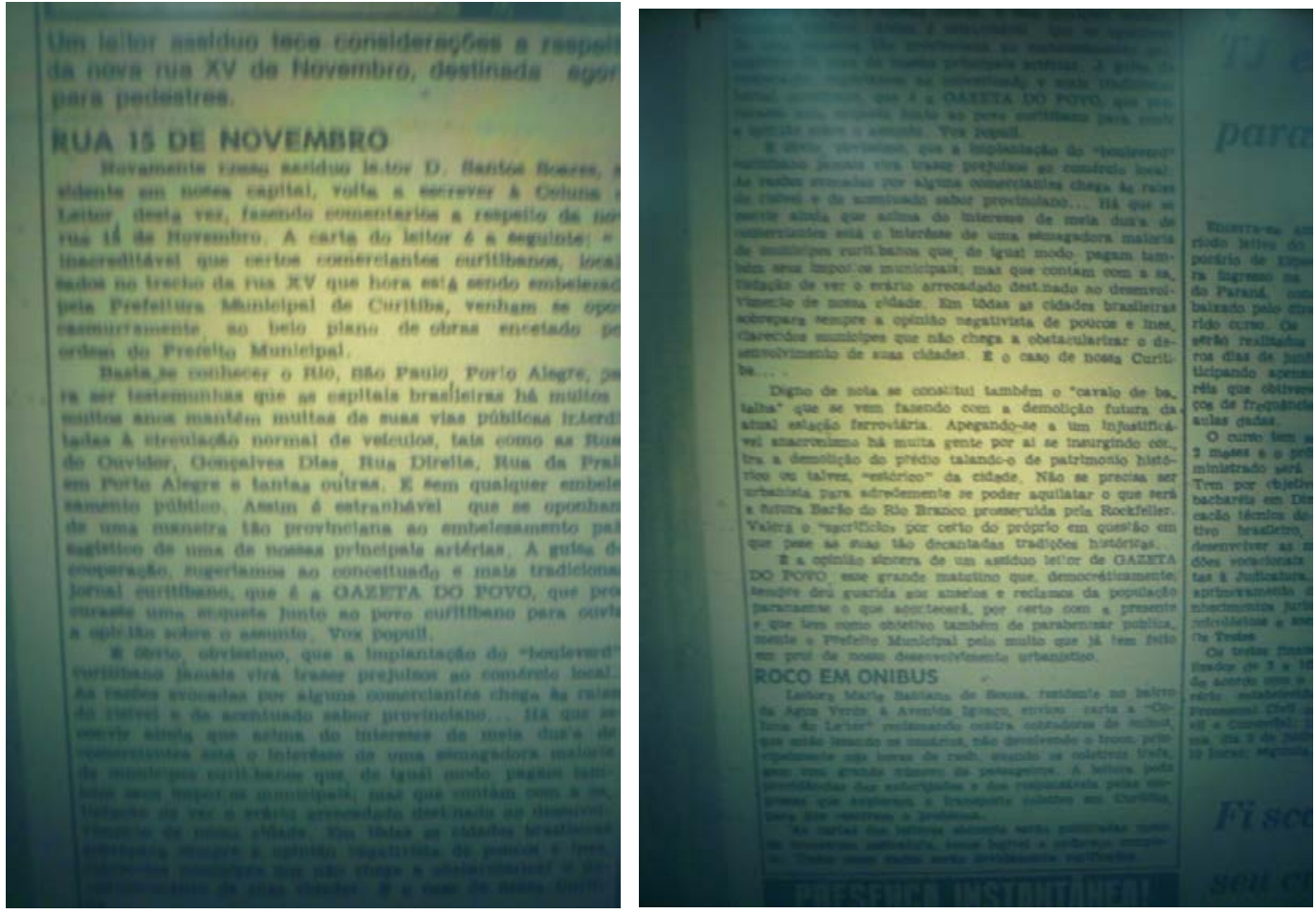


\section{RESUMO}

O presente artigo busca relacionar a dinâmica de transformação urbana de uma cidade, no caso específico o processo de pedestrização da Rua XV de Novembro de Curitiba, com a construção de imagens e significados da mesma - um espaço-tempo educativo para além da escola - a partir dos diversos atores envolvidos. Esse processo é entendido como uma rede educativa que se forma num cotidiano multifacetado - vertical, se considerarmos a relação de tempo; horizontal, se considerarmos a relação entre os atores envolvidos. Para tanto é utilizada a Teoria SCOT, que visa investigar divergências e paralelismos dentre os posicionamentos dos vários atores que contribuíram para a construção histórico-social desse artefato e assim comprovar a interdependência entre o resultado e as variáveis do processo.

Palavras-chave: Construção histórico-social. Educação para além da escola. Pedestrização.

\section{MEN WHO TRANSFORM THE CITY THAT TRANSFORM MEN: THE CURITIBA'S CASE}

\section{ABSTRACT}

The present article seeks to relate the dynamics of urban transformation of a city, in the specific case the process of pedestriation of The $X V$ de Novembro Street in Curitiba, with the construction of images and meanings of it - an educational space-time beyond school - the various actors involved. This process is understood as an educational network that is formed in a multifaceted daily - vertical, if we consider the relation of time; horizontal, if we consider the relationship between the actors involved. In order to do so, the SCOT Theory is used to investigate divergences and parallels among the positions of the various actors that contributed to the historical-social construction of this artifact and thus to prove the interdependence between the result and the process variables.

Keywords: Historical-social construction. Education beyond school. Pedonization.

\section{HOMBRES QUE TRANSFORMAN LA CIUDAD QUE TRANSFORMA LOS HOMBRES: EL CASO DE CURITIBA}

\section{RESUMEN}

El presente artículo busca relacionar la dinámica de transformación urbana de una ciudad, en el caso específico el proceso de pedestrización de la calle XV de noviembre de Curitiba, con la construcción de imágenes y significados de la misma - un espacio-tiempo educativo más allá de la escuela - a de los diversos actores involucrados. Este proceso es entendido como una red educativa que se forma en un cotidiano multifacético - vertical, si consideramos la relación de tiempo; horizontal, si consideramos la relación entre los actores involucrados. Para ello se utiliza la Teoría SCOT, que busca investigar divergencias y paralelismos entre los posicionamientos de los diversos actores que contribuyeron a la construcción histórico-social de ese artefacto y así comprobar la interdependencia entre el resultado y las variables del proceso.

Palabras clave: Construcción histórico-social. Educación más allá de la escuela. Peatonalización. 